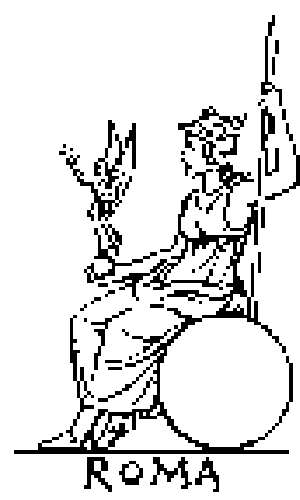

An Inscription Recently Found at Bordeaux

Author(s): Paul Courteault

Source: The Journal of Roman Studies, Vol. 11 (1921), pp. 101-107

Published by: Society for the Promotion of Roman Studies

Stable URL: http://www.jstor.org/stable/295889

Accessed: 09/05/2014 01:22

Your use of the JSTOR archive indicates your acceptance of the Terms \& Conditions of Use, available at http://www.jstor.org/page/info/about/policies/terms.jsp

JSTOR is a not-for-profit service that helps scholars, researchers, and students discover, use, and build upon a wide range of content in a trusted digital archive. We use information technology and tools to increase productivity and facilitate new forms of scholarship. For more information about JSTOR, please contact support@ jstor.org. 


\section{AN INSCRIPTION RECENTLY FOUND AT BORDEAUX.}

(Plate viri).

By Professor PAUL COURTEAULT.

In the autumn of I92I a scheme for the extension of the Exchange at Bordeaux led to the demolition of certain properties in the Rue du Pont-de-la-Mousque. During the operations the workmen encountered the original Roman wall of the town, built about A.D. 300 as a result of the great invasion of A.D. 276.1 The Chamber of Commerce, on the enlightened initative of their President, M. Etienne Huyard, decided to follow up the discovery by a systematic and careful excavation. The decision was justified by its happy results. Many interesting objects which had been utilized as building material were brought to light. These included a votive altar with an inscription which is of peculiar importance because of the light which it throws on the early relations of Gaul and Britain. A brief account of it may not be unwelcome to readers of the Fournal of Roman Studies.

As might have been expected, it was the lower courses of the wall that yielded the most interesting remains. The monument here described came from the third course. It was embedded in the cellar wall of No. 6 Rue du Pont-de-la-Mousque. The block was discovered on December I 3 th, and it proved possible to disengage it almost without damage. It is of sandstone, whereas all the other surviving remains are of local limestone. When examined, it turned out to be a portion-and the major portion-of an altar, of quadrangular shape, consisting of a die, a base and a pedestal. The entablature is missing. The die is complete. The bas-relief above it, on the other hand, is mutilated; what is left of it is broken in two, but luckily the fragments could be fitted together exactly. The base was also broken, but has been reconstructed almost in its entirety. Of the pedestal we have only a piece of a corner. The actual height of the monument is $98 \mathrm{~cm}$.; with the pedestal it may have been as much as $\mathrm{I} \cdot 24 \mathrm{~m}$. The base is $80 \mathrm{~cm}$. broad and $70 \mathrm{~cm}$. deep, the die $65 \mathrm{~cm}$. broad and $60 \mathrm{~cm}$. deep. The pedestal had had a torus; the profile of the base shows a listel, an ogee curve, and a listel.

The face of the die (plate virI, no. I) bears an inscription, occupying a space of $42 \mathrm{~cm}$. $\times 47 \mathrm{~cm}$. and enclosed within two fluted pilasters, which rest upon a base with a double moulding and which are continued upwards so as to serve as a framework for the bas-relief above.

\footnotetext{
${ }^{1}$ C.. C. Jullian, Histoire de la Gaule iv. pp. 598602 ; and, on the walling of Bordeaux, Leo Drouyn,

Bordeaux vers $145^{\circ}$, pp. $3-7$, and Jullian, Inscr. rom. de Bordeaux ii. pp. 284-303, 587-589.
} 
The latter extends over the whole breadth of the die. What is left of it is $37 \mathrm{~cm}$. high. Resting on a band, $12 \mathrm{~cm}$. high and decorated with five palmettes, is a group of figures which still rises to a height of $25 \mathrm{~cm}$.

The inscription is arranged in eight lines. The average height of the letters is $4 \mathrm{~mm}$., except in line 3 where it falls to $3 \mathrm{~mm}$., although only for the first two words. The letters are very regularly formed and very: well cut. The words are separated by triangular stops, deeply graven. As will be seen from the printed copy; the stops are occasionally omitted and ligatured letters are frequent. The cross bars of the letters $\mathrm{A}$ and $\mathrm{E}$ are always straight ; the central bar of $\mathrm{E}$ is sometimes of the same length as its two companions, sometimes shorter. The peak of $\mathrm{A}$ is emphasized by a short horizontal stroke, the terminal curve of $G$ by a triangular stop. In consequence of the stone being worn, the middle part of line 4 is hardly legible. So, too, the last $\mathrm{A}$ in line 6; here nothing is visible except the stroke emphasizing the peak of the letter.

The following is the reading adopted by M. C. Jullian after a personal examination of the stone :-

\author{
DEAE $\cdot$ TVTELE BOVDIG \\ $\mathrm{M} \cdot \mathrm{A} / \mathrm{R}$ L.VNARIS IIIIII \\ $\mathrm{VIR} \cdot \mathrm{A} / \mathrm{G} \cdot \mathrm{COL} \cdot \mathrm{BOR} \cdot \mathrm{ET}$ \\ $\mathrm{IND} \cdot \mathrm{ROV} \cdot \mathrm{BRIT} \cdot \mathrm{IN}$ \\ $\mathrm{ARAM} \cdot \mathrm{OIA \Lambda} \cdot \mathrm{VOV} \mathrm{R}$ \\ $\mathrm{AB}$ BORACI $\cdot$ AVEE \\ $\mathrm{V} \cdot \mathrm{S} \cdot \mathrm{L} \cdot \mathrm{M}$ \\ PERPEVO $\mathrm{E} \cdot \mathrm{CORNE}$
}

\begin{abstract}
Deae Tutel(a)e Boudig(ae) | M(arcus) Aur(elius) Lunaris se | vir Aug(ustalis) col(oniarum) Ebor(aci) et $\mid$ Lind(i) prov(inciae) Brit(anniae) Inf(erioris) | aram quam vover(at) | ab Eboraci avect(us) | $v($ otum) s(olvit) l(ibens) m(erito) |Perpetuo et Corne(liano consulibus). 'In honour of the goddess Tutela Boudiga, M. Aurelius Lunaris sevir Augustalis of the coloniae of York and Lincoln, in the province of Lower Britain, [set up] the altar which he vowed on starting from York. Willingly and rightly did he fulfil, his vow, in the consulship of Perpetuus and Cornelianus.'

The inscription is dated; the consulship of Perpetuus and Cornelianus corresponds to the year A.D. 237. ${ }^{1}$ The fact is worth noting, for consular dates are rare on the inscriptions found at Bordeaux. Previously only two were known-those on the pedestal of the statue of Tutela (A.D. 224) and on the cippus of Domitia (A.D. 42)-unless we add that on the statue of the Emperor Claudius
\end{abstract}

\footnotetext{
${ }^{1}$ Groag in Pauly-Wissowa, Real-Encyclopädie iv, 1249.
} 
(A.D. 258), no longer extant, and that on the monument of Gordian (A.D. 238$).{ }^{1}$

The language presents no peculiarity except the form EBORACI in line 6 , which seems to be a locative. ${ }^{2}$ Otherwise the inscription is perfectly in order.

What we have here is a dedication to Tutela, with the epithet Boudiga. It is easy to recognize in this appellation the name of Queen Boudicca, the national heroine of the Britons, who headed the great revolt against the Roman yoke in A.D. 6r. ${ }^{3}$ Boudicca, a Celtic word, means 'the Victorious,' 4 just as does Andarta, a Vocontian divinity, whose Roman name is Victoria. ${ }^{5}$

The dedicator, Marcus Aurelius Lunaris, ${ }^{6}$ is a Briton, a circumstance which immediately explains the bestowing on Tutela of the name Boudiga. $\mathrm{He}$ is described as sevir Augustalis. This means that he belonged to the corporation of the Augustales, which formed an ordo in the municipalities, ranking next after the decurions and having as its special function the maintenance of the imperial cult. ${ }^{7}$ Lunaris was a sevir of the coloniae of Eburacum (York) and Lindum (Lincoln). Lincoln was, of course, on the route from London to York. ${ }^{8}$ Its modern name enshrines the memory of its ancient status-Lin $(\mathrm{dum}) \operatorname{col}(0) n(i a)$. The only literary evidence for its having been a colonia is a reference in Ravennas, ${ }^{9}$ but the new inscription brings further confirmation. As for York, epigraphic testimony to the fact that it too was a colonia has long been on record. ${ }^{10}$ Ptolemy ${ }^{11}$ makes it the station of Legio VI Victrix, and his statement is amply borne out by inscriptions. From the latter part of the first century-when it was occupied by Legio IX Hispana, afterwards annihilated by the Brigantes-it was one of the three chief military centres of the province of Britain, the others being Chester and Caerleon. The circumstance that here, as at Lincoln, the great majority of the inscriptions related to legionaries led Hübner to argue that the town must have been first and foremost a fortress and that it can have had little importance otherwise. ${ }^{12}$ Nevertheless the thirty inscriptions which he mentions include one which relates, as does ours, to a sevir Augustalis, M. Verecundius Diogenes. It

\footnotetext{
1 C. Jullian, Inscr. rom. de Bordeaux. Nos. 20, 6r, 26, 29 (C.I.L. xiii, 584, 633, 590, 592).

${ }^{2}$ Holder, Altceltischer Spracbsatz i, 1395 f. gives : obiit in Britannia Eboraci and perit Eboraci, but no example following $a b$.

3 Tac. Ann. xiv, 29, 35; Agric. 14-r6. Dio, Ixii, 7 .

${ }^{4}$ Holder (op. cit. i, 497), following d'Arbois de Jubainville, derives it from the root boudi 'profit.' Cf. the adjective boudius =victoriosus.

5 C. Jullian, Notes gallo-romaines. Sainte Victoire, Victoria, Andarta (Rev. des Et. anc, 1899, p. 49).

${ }^{6}$ The cognomen Lunaris is very uncommon. But it was borne by a Roman soldier who fell in
}

Dacia, probably in Domitian's wars (Dessau, Inscr. Sel. 9ro7). Moreover it occurs in Britain, on a tombstone found at Brougham Castle in Cumberland (Epbem. Epigr. iii, 87).

${ }^{7}$ Daremberg and Saglio, s.v. Augustales.

${ }^{8}$ Cf. Itin. Ant. p. 475,3 , p. 476,7, p. 477,9 , p. 478 , Iо.

${ }^{9}$ v. $3 \mathrm{r}$, p. 430,2 . The inscriptions found at Lincoln relate chiefly to legionaries.

10 C.I.L. vii, 248.

11 Geogr. ii, 3, 10.

12 Ceterum splendor coloniae non videtur magnus fuisse, quoad quidem ex titulis reliquiisque aedificiorum conjectum fieri potest (C.I.L. vii, p. $6 \mathrm{r}$ ). 
is the inscription which speaks of York as a colonia. The Bordeaux inscription, which undoubtedly introduces us to a negotiator, seems to indicate that the place had some importance from the economic point of view. The assigning of Eboracum and of Lindum to Lower Britain is to be interpreted in the light of the division of Britain into two provinces, Britannia Superior and Britannia Inferior, carried out by Septimius Severus in A.D. 197. We already knew, from Dio and from inscriptions, that Eboracum was in Lower Britain. ${ }^{1}$ That the same was true of Lindum, we now learn for the first time. The information is valuable. It proves that the frontier cannot have run near York, as has hitherto been generally assumed. ${ }^{2}$ It must have run some distance to the south.

The inscription of Lunaris is of first-rate importance as illustrating the economic relations of Bordeaux with Britain. The existence of these relations is familiar to us through the text of Strabo, who speaks of the mouth of the Garonne as one of the four points of embarkation for crossing from the continent to the island. ${ }^{3}$ An extant inscription mentions a native of Trèves, who died at Bordeaux about the middle or end of the first century, and who is described as neg(otiator) Britan(nicianus), ${ }^{4}$ which shows that he carried on an export and import business with Britain. But, among the thirty-two inscriptions that have come to light at Bordeaux with the names of immigrants, though one meets Gauls, Spaniards and Greeks, including two Asiatic Greeks, there was not a single one relating to a Briton. This is the first. It bears witness to the commercial connexion that was maintained between Bordeaux and the towns in the interior of the island in the third century or, in other words, at the most brilliant period in the history of the Gallo-Roman municipality.

Ought the monument set up by Lunaris, after his voyage from York to Bordeaux, to be regarded as a simple private $e x$-voto, a token of gratitude to the divinity that had secured him a good crossing ? Perhaps we may see in it something else and something better. The inscription is dated A.D. 237. In it Tutela is given the epithet 'Victorious.' Now 237 is the year immediately subsequent to the great expedition of Maximianus into Germany. The successor of Alexander Severus, resuming the great plan of the young prince whose throne he occupied, crossed the Rhine at the head of a considerable army, drove back the Germans, marched nearly 200 miles over enemy territory, and penetrated as far as the Elbe. 'Il y avait,' says M. Jullian, 'deux cent trente ans que, depuis l'expédition de Tibère, les légions romaines n'étaient plus arrivées sur les bords du

\footnotetext{
${ }^{1}$ Dio $1 \mathrm{v}, 23 ;$ C.I.L. viii, $5 \mathrm{r} 80$.

${ }^{2}$ Hübner in Pauly-Wissowa, Real-Encyclopädie, iii, 878 ; von Domaszewski in Rheinisckes Museum, x!viii, 345; Haverfield, Arcb. Oxomensis, 1894, 9 .
}

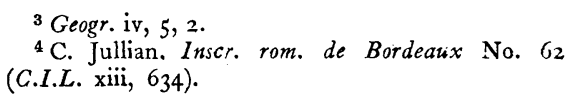


fleuve célèbre. Ce retour victorieux à la lueur des incendies montrait à toutes les nations l'éternelle vigueur du peuple romain.' 1 This triumphal march right across Germany, this splendid victory, struck contemporary imagination. It is natural to suppose that the sevir of York and of Lincoln, who had heard of it at the moment of his departure (avectus) had resolved, in a flush of patriotic enthusiasm and of gratitude on behalf of the Caesar whose priest he was, to commemorate, on his arrival at Bordeaux, the magnificent effort of Rome against the menace of barbarism. The monument which he set up ought to be compared with that which was consecrated at Bordeaux Victoriae Augustorum et Caesarum, and which M. Jullian connects with one of the victories gained by Maximianus or Constantius Chlorus over the barbarians of the Rhine between 293 and $305 .^{2}$ We must also compare it with the two altars from Lyons, erected to the Magna Mater for the well-being of Septimius Severus and dated in the years when the Emperor was campaigning in Asia Minor (194) and in Mesopotamia (197). ${ }^{3}$ In point of fact, it was to the Phrygian Magna Mater, transformed under the Empire into a guardian goddess of the Caesars and of the Roman arms, into a goddess who wins and who brings victory, that Lunaris dedicated his ex-voto. There is all the less reason to be surprised at this, since the cult of the Great Mother had spread in Britain. ${ }^{4}$ The Idaean goddess had been assimilated there to native beliefs : hence the Celtic name of Boudicca which she bears on the Bordeaux inscription. Our monument, therefore, seems to be an ex-voto set up by a private individual on the occasion of a great public event.

The bas-relief above interprets the inscription pictorially. It represents the sacrifice which Lunaris proceeded to offer. In the centre is Tutela, seated to front, clad in a robe which extends to her feet and the neck of which can be seen. Her head, which is missing, must have been turreted. In her left the goddess holds a cornucopiae. 5 On the lower part of her body, beneath very fullydeveloped breasts, is a disc-unquestionably the tympanum, a very ancient attribute of Cybele and symbolical of the terrestrial globe. ${ }^{6}$ In her lap, between her knees, three circular objects, placed one above another, seem to be the cymbals, another attribute of Cybele. Beside them is a bunch of ears of corn and perhaps of poppies, which lies along the goddess's left thigh. This bunch may be compared with that which is seen in the hand of the Empress Livia on a well-

\footnotetext{
${ }^{1}$ C. Jullian, Histoire de la Gaule, iv, pp. $547 \mathrm{f}$.

2 Inscr. rom. de Bordeaux No. 22 (C.I.L. xiii, 1753 ). It is no longer extant.

${ }^{3}$ Espérandisu, Nos. 1738 f. (C.I.L. xiii. 1754). Cf. Graillot, Le Culte de Cybèle, igı , p. 46ז.

${ }^{4}$ Graillot, op. cit. pp. 472 f. For an opposite view, see von Domaszewski in F.R.S. i, pp. 50 ff. where it is pointed out that the cult could hardly
}

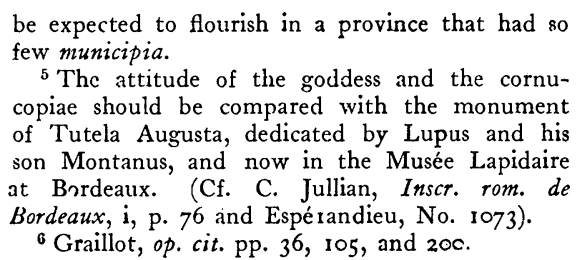
few municipia.

5 The attitude of the goddess and the cornucopiae should be compared with the monument of Tutela Augusta, dedicated by Lupus and his son Montanus, and now in the Musée Lapidaire at Bordeaux. (Cf. C. Jullian, Inscr. rom. de Bordeaux, i, p. $7^{6}$ and Espé randieu, No. 1073). ${ }^{6}$ Graillot, op. cit. pp. 36, 105, and 200. 
known cameo, in which she is represented with the attributes of Cybele. ${ }^{1}$ In her right Tutela seems to hold a sacrificial cake or a patera. To right of her is a bull, an animal sacred to Cybele and sacrificed in her mysteries. It occurs elsewhere on the right of Tutela-standing, with its forefeet planted on a small altar, on the monument of Lupus and Montanus, and kneeling, to the left of a bust of Attis, on an altar in the Museum at Périgueux. ${ }^{2}$ Here it is shown standing to front. The head, the horns, and the forehoofs are clearly distinguishable. Above the bull is a tree, undoubtedly the sacred pine of Cybele, which occurs also on the Périgueux altar. To the right of the bull is a priest, recognizable by his Phrygian cap. On Tutela's left stands the dedicator himself, clad in a long tunic, with a mantle attached to his shoulder, his left arm by his side, his right arm extended, in the act of sacrificing. Between the goddess and her worshipper is an altar, surmounted by a triangular pediment and having its base resting on a stand.

Compared with the two human figures, Tutela appears to be of colossal size. As the relief is a reproduction of the actual scene of the sacrifice performed by Lunaris, may we not suppose that the representation of the goddess is a copy of the colossal statue that must have stood in the cella of the temple of Tutela at Bordeaux, and that there, as here, we must see her with her attributes of ritual and a bull by her side? In any event, this representation confirms the view that the cult of Tutela, very popular in Gaul, particularly to the south of the Loire, was assimilated to that of the PhrygioRoman Magna Mater and that the Lady of the taurobolia was identified with Boudicca, the Celtic goddess of Victory. ${ }^{3}$

On the lower part of the left side of the altar, within a framework formed of two fluted pilasters, is a sculptured bas-relief, $37 \mathrm{~cm}$. high and $40 \mathrm{~cm}$. broad (plate viII, no. 2). It represents a god, naked to waist, the muscles of his breast very prominent, the lower portion of his body draped in an ample robe, the folds of which spread out over the ground. His head, which is turned to left, has a thick crop of hair and is horned; his face is bearded. The god is seated, his right leg bent back. His left arm and leg are stretched out at full length, and his left hand holds an inverted anchor. His right arm, which is bent back, is resting on a vase from which flows a stream of water. It is a representation of the Garonne, the river that carried Lunaris to Bordeaux. In Latin, of course, all river-names, even those which end in $a$ are masculine; it is so with the Garonne. ${ }^{4}$

\footnotetext{
${ }^{1}$ Bernouilli, Röm. Ikonogr. II, i, p. 94 , No. 3 B (Pl. xxvii, 2). Cf. Graillot, op. cit. pp. iii f.

2 Espérandicu, No. 1267.

${ }^{3}$ Graillot, op. cit. p. 46 r. C. Jullian, Hist. de la Gaule, vi, p. 66, n. 2.

${ }_{4}^{4}$ Tibullus (i, 7, I I) has Magnusque Garunna; Strabo

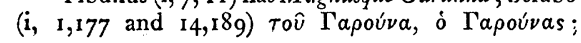

Mela $(3,2,21)$ Garunna ex Pyrcnaeo monte delapsus. In the fourth century Ausonius (Mos. 483; Epist. I0, 13; 14, I; 26, 74) and Paulinus of Pella (Eucbarist. 44-46) were the only authors who made the river Garonne feminine. In the fifth century Sidonius Apollinaris (Epist. 8, 7, 5 ll. 44 ff.; II, 3 , 1. $3 \mathrm{I}$; Carm. $7,11.393$ f.) restored it to its mascu- 

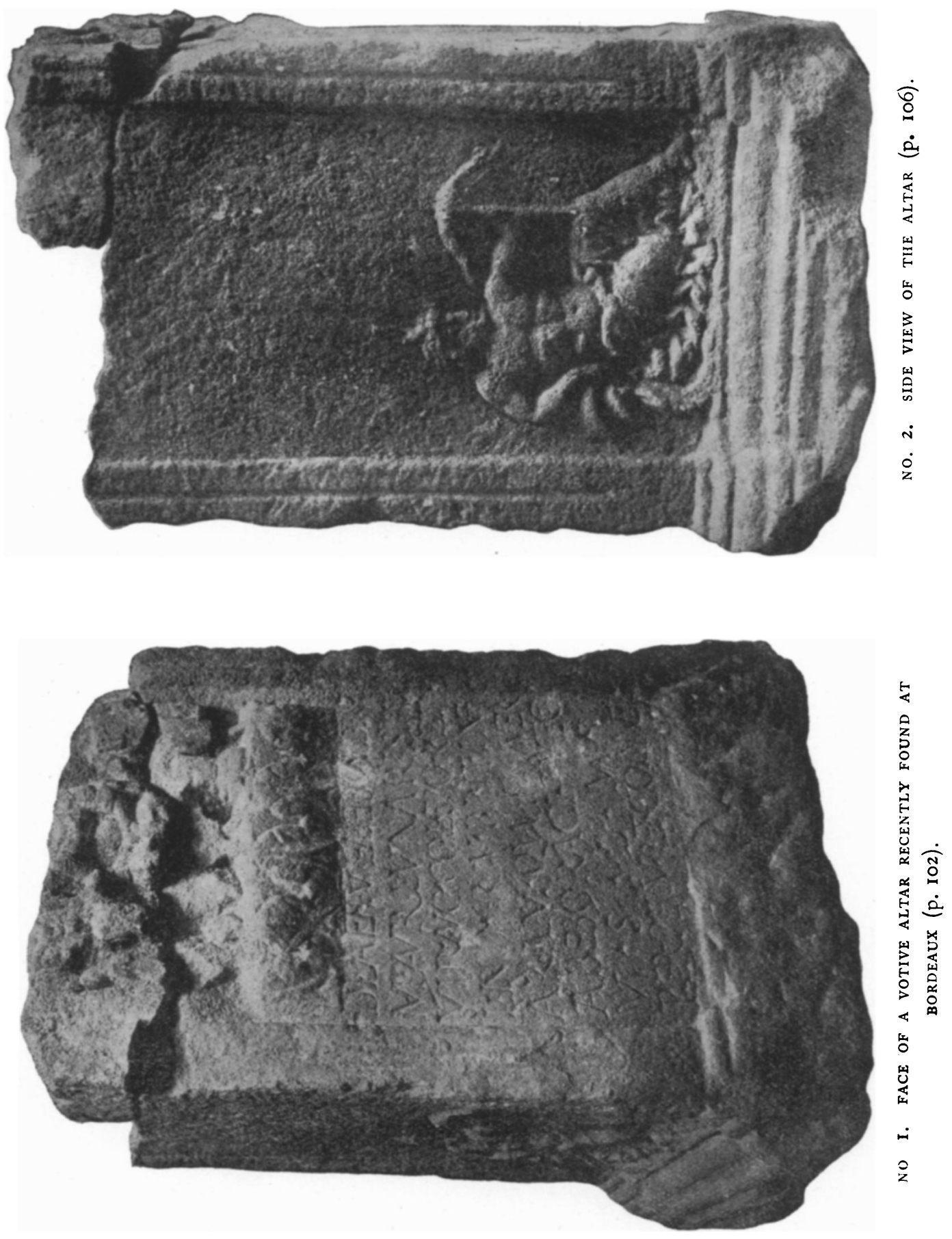
The anchor is apparently the symbol of the harbour where shipping put in. This figure is of much interest; it is the only known representation of the Garonne.

On the right side of the altar, also within a framework, is another bas-relief, this time in the upper part. It is a boar, $20 \mathrm{~cm}$. high and $30 \mathrm{~cm}$. long, seen in profile towards the left. His four feet, his eye, his tusks, his bristles and his tail are all discernible. The animal is placed on a stand which serves as the capital of a pilaster. We must interpret this as the 'canting badge' of the town of York. In point of fact Eboracum comes from the root ebor-(ebur-), which in Celtic means a boar. ${ }^{1}$ It appears again in the name of a Gaulish tribe, the Eburones, ' the children of the boar.' This emblem would suggest that York reared herds of swine; the old name of the town would then be a reminiscence of the industry that brought it fame. However that may be, the boar of York is a pendant to the Garonne or, in other words, to Bordeaux. Lunaris has put upon his monument a figure of the town from which he set out and of that at which he arrived, as if he wished, not merely to recall the happy issue of his voyage, but to give visible expression to the economic relations between Britain and Bordeaux, already illustrated by the inscription. Like the bas-relief above, the two reliefs on the sides furnish a most satisfactory commentary upon, and explanation of, the actual words of dedication.

line gender (Holder, Altceitischer Spracbs. I, I98587). Cf. an article by M. de La Ville de Mirmont in the Petite Gironde for 7 th Jan. 1922.
${ }^{1}$ Cf. C. Jullian, Histoire de la Gaule, ii, p. 35, n. 2 and p. 36 , n. 4 . M. Jullian cites the analogy of the German Eber. 